\title{
FAKTOR YANG BERHUBUNGAN DENGAN MOTIVASI MENYIMPAN HASIL PANEN PADI PETANI DI KABUPATEN SELUMA
}

\author{
The Factors That Related to Motivation in Saving The Harvest of \\ Farmers in Seluma
}

\author{
Ayu Paramita Kusuma, Basuki Sigit Priyono, dan Sriyoto \\ Jurusan Sosial ekonomi Pertanian Fakultas Pertanian Universitas Bengkulu
}

\begin{abstract}
The purposes of this research are to 1) estimate the frequency of sale until the next harvest season, 2) examine the reasons for saving the crops of rice farmers do, 3) reveal motivation of rice farmers to store their products, and 4) analyze the factors related to the motivation of storing crops of rice farmers in the County of Seluma. The results showed that the frequency of the sale of the crops that farmers is low. Economic reasons farmers saving the crops with the largest percentage of $36,67 \%$ was to be sold again to the urgent needs and social reasons farmers save percentage with yields equal to $8.33 \%$ is there is often a relative/neighbor who borrowed. The level of motivation of farmers in storing the rice harvest is at a high percentage of category $68,33 \%$. Non formal education factor and experience farming has a real connection with the motivation of saving crops of rice farmers in Seluma. Factors of age, formal education, land area, number of family dependants, and number of previous production doesn't have a real relationship with the motivation of storing crops of rice farmers in the County of Seluma.
\end{abstract}

Keywords : Motivation, Product Saving, Paddy

\section{PENDAHULUAN}

Akhir- akhir ini berbagai media melaporkan adanya ratusan hingga ribuan anak balita diberbagai wilayah Indonesia yang mengalami gizi buruk. Kondisi ini dikarenakan banyak penduduk tidak memiliki akses terhadap sumber produksi pangan, terutama tanah dan pendapatan yang cukup. Hal ini menunjukkan bahwa masalah ketahanan pangan menjadi isu penting yang harus dicarikan solusinya. Salah satu upaya yang dapat dilakukan adalah dengan penyediaan pangan yang cukup. Untuk penyediaan pangan yang cukup harus melalui peningkatan produksi sub sektor tanaman pangan khususnya tanaman padi (Kesumayanti, 2006).

Berbicara masalah pangan, padi merupakan primadona tanaman pangan dan merupakan tanaman paling utama di Indonesia. Dalam era perdagangan bebas yang semakin dekat, mengharuskan setiap negara untuk 
mempersiapkan diri. Indonesia dalam upayanya menghadapi persaingan internasional mempunyai keunggulan dalam bidang pertanian. Sejarah pembangunan pertanian Indonesia sejak PELITA I sampai dengan sekarang telah membuktikan bahwa sektor pertanian mempunyai peranan yang sangat besar dalam perekonomian nasional, sehingga pembangunan pertanian merupakan bagian penting dan tidak dapat terpisahkan dari pembangunan ekonomi dan pembangunan nasional (Kesumayanti, 2006).

Kabupaten Seluma merupakan satu wilayah penghasil pangan di Propinsi Bengkulu, yang dalam satu dekade terakhir mengalami penurunan produksi. Munculnya beberapa perusahaan perkebunan kelapa sawit di wilayah ini mempunyai pengaruh besar terhadap orientasi petani padi. Para petani menyimpan hasil panennya, sehingga mereka tidak pernah kekurangan pangan sepanjang tahun. Namun demikian, orientasi ini telah berubah ke arah komersial karena sebagian petani padi telah mengkonversikan (sebagian atau seluruh) lahan sawahnya menjadi kebun-kebun kelapa sawit yang lebih menjanjikan masa depannya. Dengan semakin sempitnya lahan persawahan menyebabkan total produksi padi semakin menurun, sehingga jumlah produk yang dapat disimpan menjadi semakin terbatas.

Motivasi petani dalam menyimpan hasil panennya ini menarik untuk diteliti karena keteguhan dari para petani yang tetap melakukan penyimpanan meskipun hasil panen yang didapat sedikit. Tentunya petani mempunyai dorongan dalam melakukan penyimpanan hasil panennya ini.

Berdasarkan latar belakang diatas, maka permasalahan yang di angkat dalam permasalahan ini adalah:

1. Berapa kali frekuensi penjualan padi petani hasil panennya sampai masa panen berikutnya?

2. Apa alasan petani menyimpan hasil panen padi di daerah penelitian?

3. Seberapa besar tingkat motivasi petani dalam menyimpan hasil panen padi di daerah penelitian?

4. Faktor apa saja yang berhubungan dengan motivasi menyimpan hasil panen padi yang dilakukan petani di Kabupaten Seluma?

Adapun tujuan dari penelitian ini adalah :

1. Mengetahui frekuensi penjualan padi hasil panen sampai musim panen berikutnya.

2. Mengetahui alasan-alasan menyimpan hasil panen padi yang dilakukan petani di Kabupaten Seluma.

3. Mengetahui tingkat motivasi menyimpan hasil panen padi petani di Kabupaten Seluma.

4. Menganalisis faktor-faktor yang berhubungan dengan motivasi menyimpan hasil panen padi yang dilakukan petani di Kabupaten Seluma. 


\section{METODE PENELITIAN}

\section{Metode Penentuan Lokasi Penelitian}

Penelitian ini dilakukan di Kabupaten Seluma, Kecamatan Seluma Selatan dan Sukaraja. Untuk pemilihan desa di Kecamatan Seluma Selatan dan Sukaraja juga menggunakan metode purposive atau sengaja yaitu Desa Rimbo Kedui dan Desa Bukit Peninjauan I. Alasan pemilihan Desa tersebut adalah dengan pertimbangan masih banyak petani yang berusahatani padi dan kedua desa merupakan sentral produksi padi di Kabupaten Seluma. Penentuan responden untuk setiap kelompok ditentukan secara simpel random sampling. Data yang dikumpulkan dalam penelitian ini adalah data primer dan data sekunder.

\section{Metode Analisis Data}

\section{Frekuensi Penjualan Padi Hasil Panen}

Untuk menjawab tujuan pertama dari penelitian ini, yaitu frekuensi penjualan padi hasil panen digunakan metode analisa deskriptif. Analisa deskriptif digunakan untuk menjelaskan secara menyeluruh tentang data atau informasi yang diperoleh dari lapangan.

\section{Alasan Motivasi Menyimpan Hasil Panen Padi}

Di tujuan kedua ini, analisis data yang digunakan adalah sama dengan analisis pada tujuan yang pertama, yaitu menggunakan analisis deskriptif. Analisis deskriptif ini dipilih karena untuk mendeskripsikan atau menjelaskan secara menyeluruh alasan motivasi menyimpan hasil panen padi yang dilakukan petani.

\section{Tingkat Motivasi Menyimpan Hail Panen Padi}

Untuk menjawab tujuan ketiga pada penelitian ini yaitu tingkat motivasi menyimpan hasil panen padi digunakan analisis skoring. Parameter ini digambarkan oleh beberapa pertanyaan alternatif.

Faktor yang Berhubungan dengan Tingkat Motivasi Menyimpan Hasil Panen Padi

Untuk mengetahui faktor-faktor apa yang berhubungan dengan tingkat motivasi petani menyimpan hasil panen padi, maka data yang dikumpulkan dianalisis dengan menggunakan analisis statistik non parametrik yaitu uji korelasi Rank Spearman (Sugiono, 2010). 


\section{HASIL DAN PEMBAHASAN}

\section{Frekuensi Penjualan Hasil Panen Sampai Musim Panen Berikutnya}

Frekuensi penjualan dapat diartikan juga sebagai seberapa banyak atau seberapa sering petani menjual hasil panennya sampai musim panen berikutnya untuk memenuhi kebutuhan hidupnya. Untuk lebih jelasnya mengenai frekuensi penjualan hasil panen sampai musim panen selanjutnya, dapat dilihat pada tabel berikut ini.

Tabel 1. Frekuensi Penjualan Padi Hasil Panen Sampai Musim Panen Berikutnya

\begin{tabular}{lccc}
\hline \multicolumn{1}{c}{ Kategori } & Jumlah (Orang) & Persentase (\%) & Rata-rata \\
\hline Rendah $(1-2)$ & 53 & 88,33 & \multirow{2}{*}{1,78} \\
Tinggi $(3-4)$ & 7 & 11,67 & \\
\hline Jumlah & $\mathbf{6 0}$ & $\mathbf{1 0 0}$ & \\
\hline
\end{tabular}

Sumber: Data Primer Diolah, 2014

Pada Tabel 1 dapat dilihat bahwa rata-rata frekuensi penjualan padi hasil panen sampai musim panen berikutnya adalah 1,78. Pada hasil penelitian ini menunjukkan bahwa persentase terbesar berada pada kategori rendah yaitu dengan rentang penjualan 1 - 2 kali. Rendahnya frekuensi penjualan hasil panen ini dikarenakan sebelum mereka menjual hasil panennya, mereka sudah memperkirakan seberapa banyak kebutuhan yang akan dipenuhi sampai panen selanjutnya. Kemudian barulah mereka memperkirakan berapa banyak hasil panen yang akan dijual dan yang akan disimpan untuk dikonsumsi sendiri.

\section{Alasan Petani Menyimpan Hasil Panen Padi}

Alasan menyimpan padi adalah suatu hal yang diungkapkan untuk mengokohkan pendapat tentang perilaku menyimpan yang bersifat opini. Alasan dalam penelitian ini akan dikelompokkan menjadi alasan ekonomi dan alasan sosial.

\section{Alasan Ekonomi}

Alasan ekonomi adalah suatu hal yang diungkapkan petani untuk mengokohkan pendapatnya tentang menyimpan hasil panen yang menjurus kearah kebutuhan hidupnya (kebutuhan ekonomi). Ada beberapa alasan ekonomi mengapa petani menyimpan hasil panennya. Untuk lebih jelasnya lagi tentang alasan petani menyimpan hasil panen akan disajikan pada Tabel 2.

Pada Tabel 2 dapat dilihat bahwa dari total 60 responden, hanya 16 orang atau $26,6 \%$ yang beralasan bahwa menyimpan hasil panen adalah untuk dikonsumsi sendiri. Mereka tidak membeli beras lagi untuk dikonsumsi. Mereka beranggapan bahwa jika membeli beras dari luar, biaya kebutuhan 
sehari-hari akan lebih banyak. Untuk alasan yang kedua yaitu agar bisa dijual lagi untuk keperluan sehari-hari. Dari 60 responden, hanya 19 orang atau sebesar $31,67 \%$ yang beralasan demikian. Keperluan sehari-hari yang dimaksudkan disini adalah seperti belanja sayur harian, membeli kopi, gula, teh, susu, telur, tempe, dan lain-lain.

Tabel 2. Alasan Ekonomi Petani Menyimpan Hasil Panen

\begin{tabular}{|c|c|c|}
\hline Alasan & Jumlah (orang) & Persentase $(\%)$ \\
\hline \multicolumn{3}{|l|}{ Alasan Ekonomi: } \\
\hline 1. Untuk konsumsi sendiri & 16 & 26,67 \\
\hline $\begin{array}{l}\text { 2. Agar bisa dijual lagi untuk } \\
\text { memenuhi kebutuhan sehari-hari }\end{array}$ & 19 & 31,67 \\
\hline $\begin{array}{l}\text { 3. Agar bisa dijual lagi untuk } \\
\text { keperluan anak sekolah }\end{array}$ & 13 & 21,67 \\
\hline $\begin{array}{l}\text { 4. Agar bisa dijual lagi untuk modal } \\
\text { usaha tani }\end{array}$ & 14 & 23,33 \\
\hline $\begin{array}{l}\text { 5. Agar bisa dijual lagi untuk } \\
\text { keperluan yang mendesak }\end{array}$ & 22 & 36,67 \\
\hline $\begin{array}{l}\text { 6. Agar bisa dijual lagi untuk } \\
\text { keperluan lebaran }\end{array}$ & 3 & 5 \\
\hline $\begin{array}{l}\text { 7. Agar bisa dijual lagi untuk biaya } \\
\text { berobat keluarga }\end{array}$ & 2 & 3,3 \\
\hline $\begin{array}{l}\text { 8. Agar bisa dijual lagi untuk bayar } \\
\text { hutang }\end{array}$ & 6 & 10 \\
\hline
\end{tabular}

Sumber: Data Primer Diolah, 2014

Pada Tabel 2 menunjukkan bahwa dari total responden 60 orang, hanya $21,67 \%$ atau sekitar 13 orang yang mengemukakan alasan mereka menyimpan hasil panen adalah agar bisa dijual lagi untuk keperluan anak sekolah. Tidak hanya untuk keperluan sehari-hari, keperluan sekolah anak juga petani andalkan dari penjualan hasil panen yang mereka simpan. Alasan selanjutnya adalah agar bisa dijual untuk modal usahatani. Dari tabel diatas dapat dilihat bahwa hanya 14 orang atau sebesar 23,33\% petani dari total responden 60 orang. Salah satu petani mengatakan bahwa, ketika mereka kekurangan modal saat melakukan usahataninya, mereka akan menjual simpanan hasil panen.

Alasan selanjutnya adalah alasan terbanyak yang dikemukakan oleh petani. Dari Tabel 2 dapat dilihat bahwa sebanyak 22 responden atau sebesar $36,67 \%$ menyatakan alasan mereka menyimpan hasil panen adalah agar bisa dijual lagi untuk keperluan yang mendesak. Jika mereka menyimpan hasil panen, mereka tidak khawatir lagi jika tiba-tiba ada keperluan yang mendesak. Mereka bisa menjual hasil panen simpanannya. Keperluan mendesak yang dimaksudkan disini adalah keperluan yag diluar dugaan mereka. Dari Tabel 2 dapat dilihat bahwa sebesar $5 \%$ atau sebanyak 3 orang dari total responden 60 orang yang beralasan bahwa mereka menyimpan hasil panen agar bisa dijual 
lagi saat lebaran. Ketika orang bingung saat menghadapi lebaran karena banyaknya kebutuhan yang harus dipenuhi, petani yang menyimpan hasil panennya tidak kebingungan lagi. Mereka akan menjual simpanan hasil panennya. Dari hasil menjual inilah mereka akan mendapatkan uang untuk membeli keperluan lebaran.

Alasan yang ketujuh yaitu agar bisa dijual lagi untuk biaya berobat keluarga. Pada Tabel 2 dapat dilihat bahwa dari total responden 60 orang, hanya 2 orang atau sebesar 3,3\%. Mereka akan menjual simpanan hasil panennya ketika ada anggota keluarga mereka yang sakit. Dan alasan yang terakhir yang diungkapkan petani adalah agar bisa dijual lagi untuk bayar hutang. Dari tabel diatas dapat dilihat bahwa sebesar 10\% atau sekitar 6 orang yang beralasan agar bisa dijual lagi untuk bayar hutang. Biasanya mereka berhutang dengan tetangga atau sanak saudara berupa uang atau beras/padi ketika simpanan hasil panen atau uang yang mereka punya tidak cukup untuk memenuhi kebutuhan. Ketika simpanan hasil panen sudah ada, barulah mereka membayar hutang.

\section{Alasan Sosial}

Setelah dikelompokkan, didapat hasil bahwa hanya ada satu alasan sosial mengenai alasan petani menyimpan hasil panen padinya. Alasan tersebut yaitu karena sering ada sanak saudara atau tetangga mereka yang meminjam simpanan padi mereka.

Dari total responden 60 orang, hanya 5 orang atau sebesar $8,33 \%$ petani yang beralasan bahwa mereka menyimpan hasil panennya karena sering ada sanak saudara/tetangga yang meminjam. Jadi ketika ada sanak saudara/tetangga yang mau meminjam simpanan panen mereka, mereka akan meminjamkannya. Dari hasil penelitian ini menunjukkan bahwa, mereka menyimpan tidak hanya untuk memenuhi kebutuhan sehari-hari saja. Ada jiwa sosial untuk membantu orang lain dengan simpanan hasil panen mereka.

\section{Motivasi Petani dalam Menyimpan Hasil Panen Padi}

Untuk lebih jelasnya lagi mengenai tingkat motivasi petani untuk menyimpan hasil panen dapat dilihat pada Tabel 3.

Tabel 3. Tingkat Motivasi Petani untuk Menyimpan Hasil Panen

\begin{tabular}{lcc}
\hline Kategori & Jumlah (Orang) & Persentase (\%) \\
\hline Rendah $(12-20)$ & 0 & 0 \\
Sedang $(21-29)$ & 19 & 31,67 \\
Tinggi $(30-38)$ & 41 & 68,33 \\
\hline Jumlah & $\mathbf{6 0}$ & $\mathbf{1 0 0}$ \\
\hline
\end{tabular}

Sumber: Data Primer Diolah, 2014 
Pada Tabel 3 dijelaskan bahwa tingkat motivasi petani dalam menyimpan hasil panen padi yang tertinggi terletak pada kategori tinggi dengan persentase sebesar $68,33 \%$ sebanyak 41 orang. Kategori sedang dengan persentase sebesar 31,67\% sebanyak 19 orang, dan kategoti rendah dengan dengan persentase $0 \%$ sebanyak 0 orang.

Hasil penelitian ini menunjukkan bahwa keinginan atau kemauan petani di Kabupaten Seluma untuk menyimpan hasil panennya hingga musim panen berikutnya tergolong tinggi. Tingginya motivasi petani ini dikarenakan adanya dorongan yang besar dari dalam diri petani untuk memenuhi kebutuhan hidupnya.

\section{Faktor yang Berhubungan dengan Motivasi Menyimpan Hasil Panen Padi}

Untuk mengkaji ada tidaknya hubungan antara variabel bebas (umur, pendidikan formal, pendidikan non formal, pengalaman usahatani, luas lahan, jumlah tanggungan dan jumlah produksi sebelumnya) dengan variabel terikat (motivasi), maka digunakan uji korelasi Rank Spearman. Hasil estimasi motivasi menyimpan hasil panen padi dapat dilihat pada Tabel 4.

Tabel 4. Hasil Perhitungan Uji Korelasi Rank Spearman

\begin{tabular}{clccc}
\hline No & \multicolumn{1}{c}{ Variabel Bebas } & $\begin{array}{c}\text { Nilai korelasi } \\
(\mathrm{rs})\end{array}$ & T hitung & $\begin{array}{c}\text { Derajat } \\
\text { hubungan }\end{array}$ \\
\hline 1 & Umur & 0,2125 & 1,656 & No signifikan \\
2 & Pendidikan Formal & 0,1411 & 1,086 & No signifikan \\
3 & Pendidikan Non Formal & 0,4016 & $3,339^{*}$ & Signifikan \\
4 & Pengalaman Usahatani & 0,3090 & $2,477^{*}$ & Signifikan \\
5 & Luas Lahan & $-0,0340$ & $-0,262$ & No signifikan \\
6 & Jumlah Tanggungan & 0,0251 & 0,191 & No signifikan \\
7 & Jumlah Produksi & $-0,1774$ & $-1,373$ & No signifikan \\
& Sebelumnya & & & \\
\hline
\end{tabular}

Sumber: Data Primer Diolah, 2014

Keterangan: $\left(^{*}\right)=$ berhubungan nyata pada tingkat kepercayaan $95 \%(a / 2=0,025)$ dengan $t$ Tabel $+/-2,024$

Dari hasil perhitungan uji statistik maka dapat dilihat bahwa variabel pendidikan non formal dan pengalaman usahatani berhubungan nyata dengan motivasi menyimpan hasil panen padi di Kabupaten Seluma. Sedangkan variabel umur, pendidikan formal, luas lahan, jumlah tanggungan keluarga dan jumlah produksi sebelumnya tidak mempunyai hubungan nyata dengan motivasi menyimpan hasil panen padi di Kabupaten Seluma.

\section{Umur}

Dapat dilihat pada Tabel 4, berdasarkan hasil uji statistik Rank Spearman diketahui bahwa variabel umur tidak berhubungan nyata dengan 
motivasi menyimpan hasil panen padi di Kabupaten Seluma, pada taraf kepercayaan $95 \%$. Ini dapat dilihat dari besarnya t hitung $(1,656)$ lebih kecil dari pada $t$ tabel $(2,024)$. Umur petani di Kabupaten Seluma beraneka ragam. Ada umut muda, tua dan sedang. Umur yang berbeda-beda maka pola pikir petani tentang kemauan/keinginan untuk menyimpan hasil panen juga berbeda. Semakin tua umur petani, belum tentu ada kemauan/keinginan petani untuk menyimpan hasil panen. Begitu juga sebaliknya, umur petani yang muda belum tentu juga ada kemauan/keinginan untuk menyimpan hasil panen. Semuanya tergantung pada pola pikir petani masing-masing.

Penelitian ini tidak sejalan dengan penelitian Listiana (2012) yang berjudul Motivasi Petani Dalam Menggunakan Benih Padi Hibrida Pada Kecamatan Natar Di Kabupaten Lampung Selatan yang menyatakan bahwa terdapat hubungan yang nyata antara umur dengan motivasi petani dalam menggunakan benih padi hibrida.

\section{Pendidikan Formal}

Pendidikan merupakan faktor penunjang bagi keberhasilan seseorang dalam melakukan suatu kegiatan, dengan adanya pendidikan diharapkan dapat membentuk pola pikir yang lebih maju termasuk cara bersikap dan bertindak sehingga diharapkan dapat membawa kemajuan bagi dirinya (Widya, 2013). Dari hasil perhitungan uji statistik Rank Spearman diketahui bahwa variabel pendidikan formal tidak berhubungan nyata dengan motivasi menyimpan hasil panen padi di Kabupaten Seluma. Ini dapat dilihat pada Tabel 5 yang menunjukkan bahwa t hitung $(1,086)$ lebih kecil dari pada $t$ tabel $(2,024)$. Hasil penelitian ini menunjukkan bahwa tinggi rendahnya pendidikan formal seorang petani di Kabupaten Seluma tidak berhubungan dengan motivasi menyimpan hasil panen padi.

Hasil penelitian ini bertolak belakang dengan penelitian Listiana (2012) yang menyatakan bahwa antara tingkat pendidikan dan motivasi petani dalam menggunakan benih padi hibrida terdapat hubungan nyata pada taraf kepercaaan 99\%. Hal ini menunjukkan bahwa semakin tinggi tingkat pendidikan petani maka semakin tinggi motivasi petani dalam menggunakan benih padi hibrida dalam usaha taninya.

\section{Pendidikan Non Formal}

Pendidikan formal juga sebagai sistem pendidikan yang bertujuan menambah pengetahuan, kecakapan dan keterampilan. Pendidikan non formal diharapkan memiliki hubungan yang nyata dengan motivasi menyimpan hasil panen padi. Pada Tabel 4 dapat dilihat bahwa besarnya t hitung pendidikan non formal $(3,339)$ lebih besar daripada $t$ tabel $(2,024)$. Ini berarti bahwa pendidikan non formal petani di Kabupaten Seluma memiliki hubungan nyata dengan motivasi menyimpan hasil panen padi. Penelitian ini mendukung 
hipotesa peneliti yang menyatakan bahwa pendidikan non formal memiliki hubungan nyata dengan motivasi menyimpan hasil panen padi.

Hasil penelitian ini menjelaskan bahwa sering tidaknya petani mengikuti pendidikan non formal ternyata berhubungan dengan kemauan petani untuk menyimpan hasil panen padinya. Karena dari pendidikan non formal inilah petani mendapatkan ilmu dan pengetahuan baru. Semakin sering petani di Kabupaten Seluma mengikuti pendidikan non formal maka pola fikir dari petani semakin meningkat. Sehingga mereka tidak hanya memikirkan untuk langsung menjual habis hasil panennya, tetapi juga berkeinginan dan termotivasi untuk menyimpan hasil panen guna memenuhi kebutuhan hidup keluarga mereka yang mungkin tidak terduga hingga panen berikutnya.

Penelitian ini tidak sejalan dengan penelitian yang dilakukan oleh Reflis dan Nurung (2012) yang menyatakan bahwa tidak ada hubungan nyata antara peningkatan pendidikan non formal dengan peningkatan motivasi petani dalam mempertahankan sistem tradisional pada usahatani padi sawah.

\section{Pengalaman Usahatani}

Lamanya petani dalam berusahatani merupakan gambaran pengalaman yang dimiliki oleh petani. Semakin lama petani melakukan usahatani, maka semakin banyak pengalaman yang dimilikinya. Petani dengan pengalaman yang banyak tentu akan mengetahui bagaimana berusahatani dengan baik. Hasil analisis dengan uji korelasi Rank Spearman diketahui bahwa nilai korelasi variabel pengalaman usahatani sebesar $(0,309)$, selanjutnya uji statistik diperoleh bahwa nilai $t$ hitung $(2,477)$ lebih besar daripada $t$ tabel $(2,024)$ maka variabel pengalaman usahatani dengan motivasi menyimpan hasil panen padi berhubungan nyata. Hasil penelitian menunjukkan bahwa pengalaman usahatani berhubungan nyata dengan motivasi menyimpan hasil panen karena lamanya pengalaman petani dalam berusahatani menjamin adanya peningkatan kemauan petani dalam menyimpan hasil panennya.

Hasil penelitian ini sejalan dengan hasil penelitian Reflis dan Nurung (2012) yang menyatakan bahwa variabel pengalaman dengan motivasi petani dalam mempertahankan sistem tradisional padi sawah berhubungan nyata.

\section{Luas Lahan}

Berdasarkan hasil uji statistik Rank Spearman diketahui bahwa variabel luas lahan tidak berhubungan nyata dan negatif dengan motivasi menyimpan hasil panen padi di Kabupaten Seluma, pada taraf kepercayaan 95\%. Ini dapat dilihat dari besarnya $t$ hitung $(-0,262)$ lebih besar dari pada t tabel $(-2,024)$. Ini berarti bahwa luas atau sempitnya lahan petani tidak ada hubungannya dengan motivasi menyimpan hasil panen. Itu semua terjadi karena petani tidak memiliki keinginan untuk menyimpan hasil panen. Seharusnya luas atau 
sempit lahan yang mereka miliki, mereka tetap menyimpan hasil panennya demi kesejahteraan hidup keluarga.

Hasil penelitian ini sejalan dengan hasil penelitian Dewandini (2010) menunjukkan bahwa terdapat hubungan tidak siginifikan. Hubungan yang tidak signifikan ini terjadi karena baik petani yang memiliki lahan sempit atau luas dapat melakukan budidaya tanaman mendong. Namun hasil penelitian ini bertolak belakang dengan hasil penelitian Prayogi (2013) yang menyatakan bahwa luas lahan luas lahan garapan petani mempunyai pengaruh yang positif terhadap motivasi kebutuhan petani melaksanakan PTT padi sawah.

\section{Jumlah Tanggungan}

Pada Tabel 4 diketahui bahwa nilai korelasi variabel jumlah tanggungan keluarga sebesar $(0,0251)$, selanjutnya uji statistik diperoleh bahwa nilai $t$ hitung $(0,191)$ lebih kecil daripada $t$ tabel $(2,024)$ sehingga variabel jumlah tanggungan keluarga dengan motivasi menyimpan hasil panen padi tidak berhubungan nyata. Banyak atau sedikitnya jumlah tanggungan kelurga tidak ada hubungannya dengan motivasi menyimpan hasil panen. mereka termotivasi melakukan penyimpanan bukan karena banyak atau sedikitnya jumlah tanggungan keluarga mereka.

Hasil penelitian ini didukung oleh hasil penelitian oleh Reflis dan Nurung (2012) menunjukkan bahwa jumlah tanggungan keluarga tidak berhubungan nyata dengan motivasi. Penelitian ini bertolak belakang dengan dengan penelitian Ekasari (2013) yang menyatakan bahwa jumlah tanggungan memiliki hubungan dengan motivasi kebutuhan petani dalam berusahatani melati di Kelompok Tani Bina Tani Kecamatan Suradadi Kabupaten Tegal.

\section{Jumlah Produksi Sebelumnya}

Jumlah produksi sebelumnya diduga akan mempengaruhi motivasi petani dalam menyimpan hasil panennya. Semakin besar jumlah produksi yang didapat petani sebelumnya, maka semakin besar juga kemauan atau motivasi petani untuk melakukan penyimpanan hasil panen padi dimusim tanam selanjutnya.

Namun dalam hasil penelitian ini didapat bahwa jumlah produksi sebelumnya tidak berhubungan nyata. Pada Tabel 4 diketahui bahwa nilai korelasi variabel jumlah produksi sebelumnya adalah sebesar $(-0,1774)$, selanjutnya uji statistik diperoleh bahwa nilai -t hitung $(-1,373)$ lebih besar daripada $t$ tabel $(-2,024)$. Petani didaerah penelitian melakukan penyimpanan tidak disebabkan oleh banyak atau sedikitnya jumlah produksi hasil panen sebelumnya. Sedikit atau banyak hasil panen yang akan didapat selanjutnya, petani akan tetap menyimpan hasil panennya. Hal ini dikarenakan petani termotivasi untuk menyimpan atas dasar kemauan dan kebutuhan. Kecuali itu juga petani sudah merasakan manfaatnya jika punya simpanan padi dari hasil 
panennya, yakni ada yang dijual jika ada kebutuhan yang tidak diduga sebelumnya.

\section{SIMPULAN DAN SARAN}

\section{Simpulan}

Berdasarkan hasil penelitian dan pembahasan yang telah dilakukan, maka dapat ditarik kesimpulan sebagai berikut:

1. Frekuensi penjualan hasil panen yang dilakukan petani rendah.

2. Alasan ekonomi petani menyimpan hasil panen dengan persentase terbesar yaitu $36,67 \%$ adalah agar bisa dijual lagi untuk keperluan yang mendesak dan alasan sosial petani menyimpan hasil panen dengan persentase sebesar $8,33 \%$ adalah sering ada saudara/ tetangga yang meminjam.

3. Tingkat motivasi petani dalam menyimpan hasil panen padi adalah tinggi.

4. Faktor pendidikan non formal dan pengalaman usahatani mempunyai hubungan nyata dengan motivasi menyimpan hasil panen padi petani di kabupaten Seluma. Faktor umur, pendidikan formal, luas lahan, jumlah tanggungan keluarga, dan jumlah produksi sebelumnya tidak memiliki hubungan yang nyata dengan dengan motivasi menyimpan hasil panen padi petani di kabupaten Seluma.

\section{Saran}

1. Faktor pendidikan non formal dan pengalaman usahatani mempunyai hubungan nyata dengan motivasi menyimpan hasil panen, maka sebaiknya petani lebih banyak mengikuti kegiatan pendidikan non formal yang diadakan oleh pihak pemerintah maupun swasta. Selain itu juga petani harus banyak belajar dari pengalaman sebelum-sebelumnya baik itu pengalaman sendiri maupun pengalaman dari orang lain agar kehidupan selanjutnya menjadi lebih sejahtera.

2. Sebelum melakukan penjualan, sebaiknya petani memperkirakan seberapa besar kebutuhan yang harus dipenuhi sampai musim panen selanjutnya untuk menghindari jika sewaktu-waktu harga hasil panen tidak stabil. Selain itu juga, hasil panen dapat tersimpan lebih lama dan bisa digunakan jika sewaktu-waktu ada kebutuhan yang sangat mendesak.

\section{DAFTAR PUSTAKA}

Dewandini, Retno Sri Kuning. 2010. Motivasi Petani Dalam Budidaya Tanaman Mendong (Fimbristylis Globulosa) Di Kecamatan Minggir Kabupaten Sleman. Skripsi. Jurusan/Program Studi Penyuluhan Dan Komunikasi Pertanian. Fakultas Pertanian. Universitas Sebelas Maret. Surakarta. 
digilib.uns.ac.id/abstrak.pdf.php?d_id=17011 (diunduh tanggal 21 Oktober 20013).

Ekasari, N. 2013. Kajian Faktor Sosial Internal yang Berhubungan dengan Motivasi Kebutuhan Petani Dalam Berusahatani Melati (Studi Kasus di Kelompok Tani Bina Tani Kecamatan Suradadi Kabupaten Tegal). http://faperta. unsoed. ac.id/content/ kajian-faktor-sosial-internal-yang-berhubungan-denganmotivasi-kebutuhan-petani-dalam (diunduh tanggal 12 Mei 2014).

Kesumayanti, T. 2006. Analisis Pemasaran dan Pola Interaksi Antara Petani Padi Dengan Lembaga Pemasaran di Desa Banding Agung Kecamatan Seginim Kabupaten Bengkulu Selatan. Skripsi. Program Studi Sosial Ekonomi Pertanian. Jurusan Sosial Ekonomi Pertanian. Fakultas Pertanian. Universitas Bengkulu.

Listiana Indah. 2012. Motivasi Petani dalam Menggunakan Benih Padi Hibrida pada Kecamatan Natar di Kabupaten Lampung Selatan. http://www. stppmedan.ac.id/pdf/Jurnal\%20Vol\%207/6\%20-\%20Indah\%20Listiana. pdf (diunduh tanggal 12 Mei 2014).

Prayogi, E.D. 2013. Motivasi Kebutuhan Petani Melaksanakan Pengelolaan Tanaman Terpadu (PTT) pada Usahatani Padi Sawah dan Faktor Sosial Ekonomi yang Mempengaruhinya. Jurusan Sosial Ekonomi Pertanian. Universitas Jendral Soedirman. http://faperta.unsoed.ac.id/en/content/ sformatplainsformat-8 (diunduh tanggal 3 juli 2014).

Reflis dan Nurung, M. 2012. Motivasi Petani dalam Mempertahankan Sistem Tradisional Pada Usahatai Padi Sawah di Desa Parbaju Julu Kabupaten Tapanuli Utara Propinsi Sumatera Utara. Staf Pengajar FAPERTA Universitas Bengkulu. http://sangsurya-wahana.blogspot.com/ 2012/04/motivasi-petani-dalam-mempertahankan.html.

(diakses tanggal 21 Oktober 2013).

Sugiono. 2010. Statistik Nonparametris untuk Penelitian. CV Alfabeta. Bandung.

Widya, Sari Katika. 2013. Faktor-Faktor Yang Berhubungan Dengan Produktivitas Tenaga Kerja Pemanen Sawit (Elaeis Guineensis) Di Pt. Alno Agro Utama Sumindo Estate Di Kecamatan Napal Putih Kabupaten Bengkulu Utara. Program Studi Agribisnis. Jurusan Sosial Ekonomi Pertanian. Fakultas Pertanian. Universitas Bengkulu. 